Fikroh : Jurnal Pemikiran dan Pendidikan Islam

Volume. 13, Number. 1, Januari 2020

p-ISSN : 2087-7501, e-ISSN : 2715-4459

H1m : 57-73

Journal Home Page : https://jurnal.stai-alazharmenganti.ac.id/index.php/fikroh

\title{
PENINGKATAN MINAT BELAJAR SISWA DENGAN METODE TGT (TEAMS GAMES TOURNAMENT) PADA PEMBELAJARAN PENDIDIKAN AGAMA ISLAMKELAS V B MI NURUL HUDA SIDOARJO
}

\author{
Muktafi Muhtar \\ IAI Al Khoziny Buduran, Sidoarjo, Indonesia \\ muktafimuhtar@email.com
}

\begin{abstract}
This research is done because the reality of teachers complained about low awareness of students to do independent taska and learning in the classroom is mostly passive students and this affects low interest in learning, especially $V B$ (fifth B) class, from the results of research that teachers only using speech methods that are considered less effective in learning because the students activity is very limited. The purpose of this research is to describe the application of TGT method (Teams games tournament) to the fifth class $(V)$ on mathematic lesson. It is able to know the students interest level on mathematic especially for geometry after using TGT (teams games tournament) method. This research uses TGT (teams games tournament) method and classroom action research by kemmis and Mc. Taggart. This researchconsist of 2 cycles with fifth $B$ class $(V B)$ as research subject at MI Nurul Huda Sidoarjo. Data collection techniques using observation and questionnaire, with observation sheet of teachers and students to support the researchs instrument. The application of TGT (Teams games tournament) method works so well through improvements in each cycle.This is indicated by increased activity of teachers and students in the learning process. Teacher activity increased from good category in cycle I to be very good in cyle II. Likewise with students activity increased during the learning process. This is evident from the observation on cycle I categorized well and increased on cycle II that categorized very good. So, there was an increasing of students interest level on mathematics subject at MI Nurul HudaSidoarjo after using TGT (Teams games tournament) method. This is evidenced by students activeness in following the teaching learning process, and evidenced from the result of students questionnaires in learing that categorized very well.
\end{abstract}

Keywords: Interest; TGT method; student activity 


\begin{abstract}
Abstrak
Penelitian ini dilakukan karena kenyataan dilapangan para guru rata-rata mengeluhkan rendahnya kesadaran siswa untuk mengerjakan tugas-tugas mandiri dan pada saat pembelajaran di dalam kelas sebagian besar siswa pasif dan hal ini berpengaruh pada rendahnya minat belajar khususnya kelas $\mathrm{V} B$, dari hasil penelitian dalam pembelajaran guru hanya menggunakan metode ceramah yang dianggap kurang efektif dalam pembelajaran karena keaktifan siswa sangat terbatasi. Tujuan dari penelitian ini adalah untuk mendiskripsikan penerapan metode TGT (Teams Games Tournament) terhadap materi bangun ruang kelas V B mata pelajaran Matematika. Dan untuk mengetahui tingkat minat belajar siswa padamateri bangun ruang Mata Pelajaran Pendidikan Agama Islamsetelah menggunakan metode TGT (Teams Games Toumament) Penelitian ini menggunakan metode TGT (Teams games Toumament), dan penelitian ini menggunakan model Penelitian Tindakan Kelas oleh Kemmis dan Mc Taggart. Penelitian ini terdiri dari 2 siklus dengan subyek penelitian kelas V B MI Nurul Huda Sidoarjo.Teknik pengumpulan datanya menggunakan Observasi dan Angket, dengan instrument yang mendukung berupa lembar observasi guru dan siswa serta angket. Penerapan metode TGT (Teams games Toumament) berjalan dengan baik melalui perbaikan-perbaikan pada tiap siklus. Hal ini ditunjukkan dengan peningkatan aktivitas guru dan siswa dalam proses belajar mengajar. Dimana aktifitas guru mengalami peningkatan pada siklus I dari kategori baik menjadi sangat baik pada siklus II. Begitu juga dengan aktivitas siswa mengalami peningkatan selama proses pembelajaran. Hal ini terbukti dari hasil observasi aktivitas siswa pada siklus I berkategori baik dan meningkat pada siklus II yaitu berkategori sangat baik.Dan peningkatan minat siswa yang ditunjukkan oleh hasil angket minat belajar siswa pada siklus I yang berkategori cukup dan meningkat pada siklus II yang berkategori sangat baik.Terjadi peningkatan minat siswa kelas V B mata pelajaran Pendidikan Agama Islam di MI Nurul HudaSidoarjo setelah menggunakan metode TGT (Teams games Tournament) dengan baik. Hal ini dibuktikan dengan keaktifan siswa dalam mengikuti proses belajar mengajar, serta dibuktikan dari hasil penelusuran hasil angket minat belajar siswa yang berkategori sangat baik.
\end{abstract}

Kata kunci: Minat; metode TGT; keaktifan siswa

\title{
A. Pendahuluan
}

Secara bahasa minat berarti kecenderungan hati yang tinggi terhadap sesuatu.Minat adalah suatu rasa lebih suka atau ketertarikan pada suatu hal atau aktifitas, tanpa ada yang menyuruh. Minat pada dasarnya adalah penerimaan akan suatu hubungan antar dirinya sendiridengan sesuatu diluar diri, semakin kuat atau dekat hubungan tersebut, semakin besar minatnya. Minat adalah suatu kondisi yang terjadi apabila seseorang melihat cirri-ciri atau arti sementara yang dihubungkan dengan keinginan-keinginan atau kebutuhannya 
sendiri. Dari pengertian diatas dapat disimpulkan bahwa minat adalah kecenderungan seseorang terhadap obyek atau sesuatu kegiatan yang digemari yang disertai dengan perasaan senang, adanya perhatian dan keaktifan berbuat.Minat mengandung unsure kognisi (mengenal), emosi (perasaan), dan konasi kehendak. ${ }^{1}$

Oleh sebab itu minat dianggap sebagai respon yang sadar, sebab jika tidak demikian, minat tidak akan mempunyai arti apa-apa. Unsure kognisi maksudnya adalah minat itu didahului oleh pengetahuan dan informasi mengenai obyek yang dituju oleh minat tersebut, ada unsur emosi karena dalam partisipasi atau pengalaman itu disertai oleh perasaan tertentu, seperti rasa senang, sedangkan unsure konasi merupakan kelanjutan dari unsure kognisi.Dari tiga unsur inilah yang diwujudkan dalam bentuk kemauan dan hasrat untuk melakukan suatu kegiatan, termasuk kegiatan yang ada disekolah seperti belajar. ${ }^{2}$

\section{B. Kajian Pustaka}

\section{Minat}

Sardiman AM, (1988) Menyatakan bahwa minat seseorang terhadap suatu obyek akan kelihatan apabila obyek sasaran berkaitan dengan keinginan dan kebutuhan seseoarang yang bersangkutan. ${ }^{3}$ Pendapat ini memberikan pengertian bahwa minat merupakan suatu kondisi yang terjadiapabila berhubungan dengan keinginan dan kebutuhan sendiri, dengan kata lain ada kecenderungan apa yang dilihat dan diamati seseorang adalah sesuatu yang berhunbungan dengan keinginan dan kebutuhan seseorang tersebut dapat dibangkitkan dengan cara menghubungkan materi pelajaran dengan suatu berita sensasional yang sudah diketahui banyak siswa.

\section{Model TGT}

Model pembelajaran kooperatif tipe Teams Games Toumament (TGT), atau pertandingan permainan tim dikembangkan secara asli oleh David De Vries dan Keath Edward (1995). Pada model ini siswa memainkan permainan dengan anggota-anggota tim lain untuk memperoleh tambahan point untuk skor mereka. ${ }^{4}$

\footnotetext{
${ }^{1}$ Indriyastuti, Buku Paket Pendidikan Agama Islamkelas (Solo: Pt Tiga Serangkai Pustaka Mandiri, 2012)

2 Moh. Uzer Usman, Menjadi Guru Profesional (Bandung: Remaja Rosda Karya, 2001)

3 Trianto. Mendesain Model Pembelajaran Inovatif-Progresif (Jakarta: Kencana Prenada Media Group, 2010)

4 Tim Dosen Unesa, Model-Model Pembelajaran Inovatif (Surabaya: Unesa University Press, 2009)
} 
TGT dapat digunakan dalam berbagai macam mata pelajaran, dari ilmu-ilmu eksak, ilmu sosial maupun bahasa dari jenjng pendidikan dasar sampai perguruan tinggi. TGT sangat cocok untuk mengajar tujuan pembelajaran yang dirumuskan dengan tajam dengan satu jawaban yang benar, meski demikian TGT juga dapat diadaptasi untuk digunakan dengan tujuan yang dirumuskan dengan kurang tajam dengan menggunakan penilaian yang bersifat terbuka, misalnya esai atau kinerja. ${ }^{5}$

\section{A. Metode Penelitian}

Penelitian ini menggunakan penelitian tindakan kelas (class room action resarch), karena digunakan untuk memecahkan masalah pembelajaran dikelas. Penelitian ini termasuk penelitian deskriptif karena menggambarkan bagaimana suatu trknik pembelajaran diterapkan dan bagaimana hasil yang diinginkan akan dicapai. ${ }^{6}$ Menurut Kemmis dan mc Taggart penelitian tindakan dapat dipandang sebagai suatu siklus spiral dari penyusunan perencanaan, pelaksanaan, pengamatan dan refleksi yang selanjutnya mungkin diikuti siklus spiral berikutnya. Dalam penelitian ini menggunakan guru bantu sebagai peneliti, penanggung jawab penuh penelitian ini adalah guru. Tujuan utama dalam penelitian ini adalah untuk meningkatkan minat belajar di kelas dimana guru secara penuh terlibat dalam penilaian mulai dari perencanaa, tindakan, pengamatan dan refleksi. ${ }^{7}$

\section{B. Hasil dan Pembahasan}

\section{Hasil Penelitian tentang Penerapan Metode TGT}

Pada bab ini dipaparkan hasil penelitian "Penerapan metode TGT (Teams Games Tournament) untuk Meningkatkan minat belajar Siswa Kelas V Mata Pelajaran Pendidikan Agama Islamdi MI Nurul Huda Sidoarjo". Data penelitian yang diperoleh berupa pengamatan aktivitas siswa dan guru saat kegiatan belajar mengajar berlangsung dan angket. Data lembar observasi diambil dari dua pengamatan yaitu data pengamatan Aktivitas siswa saat pembelajaran berlangsung dan aktivitas guru dalam mengelola metode TGT (Teams Games Tournament) yang digunakan untuk mengetahui bagaimana penerapan metode'TGT (Teams Games Tournament) dalam

\footnotetext{
5Supriyanto, Didik. "Modeling," Jurnal Program Studi Pgmi $\quad 2, \quad$ No.2 $\quad$ (2015). Http://Jurnal.Stitnualhikmah.Ac.Id/Index.Php/Modeling/Article/View/67.

${ }^{6}$ Sugiyono, Metode Penelitian Kuantitatif Kualitatif Dan Rd (Bandung: Alfabeta, 2008)

${ }^{7}$ Sumanto Y. D, Gemar Matematika (Jakarta: Pusat Perbukuan Departemen Pendidikan Nasional, 2008)
} 
meningkatkan minat belajar siswa. Berikut hasil observasi yang dilakukan oleh peneliti pada siklus I dan Siklus II:

Table 4.1

Observasi Aktifitas Guru Selama Proses Pembelajaran Melalui Metode TGT (Teams Games Tournament) Siklus I

Kegiatan Indikator

Observer

Tahap 1. Guru mengucapkan salam

Awal 2. Guru menyampaikan topik yang diajarkan

3. Guru memberi apersepsi

4. Guru memberi motifasi tentang pentingnya belajar Pendidikan Agama Islambagi kehidupan

5. Guru memberi penjelasan materi bangun ruang

6. Guru membentuk kelompok menjadi 5 kelompok

7. Guru menyediakan media yang dibutuhkan

Tahap 8. Guru menyampaikan semua tujuan pelajaran yang Inti ingin dicapai pada pelajaran tersebut.

9. Guru menjelaskan kepada siswa bagaimana caranya membentuk kelompok belajar dan membantu setiap kelompok agar melakukan transisi secara efisien

10. Guru mengorganisasikan siswa menjadi 5 kelompok, masing-masing kelompok terdiri dari 8-9 siswa. Untuk melakukan diskusi.

11. Guru memberikan contoh kepada siswa tentang aturan permainannya.

12. Guru menyuruh salah satu kelompok mengambil kartu soal dan cari pertanyaan pada lembar permainan

13. Guru menyuruh masing-masing kelompok menjawab soal yang diberikan oleh kelompok lain atau memberi sanggahan.

$\begin{array}{llll}1 & 2 & 3 & 4\end{array}$

14. Guru mengamati kegiatan siswa dan memberikan bantuan kepada siswa yang mengalami kesulitan.

5. Guru memberikan penguatan tentang materi yang sudah dibahas yakni materi bangun ruang.

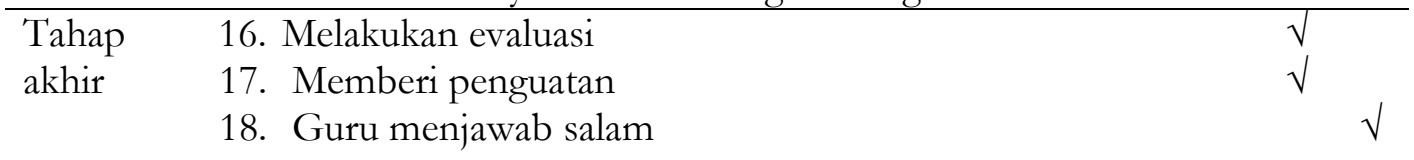

Nilai Akhir

Nilai $=\frac{\text { Skor Perolehan }}{\text { Skor Maksimum }} \times 100 \%$

Keterangan: Skor maksimum 72 


$$
\text { Nilai }=\frac{56}{72} \times 100 \%=77,77
$$

Tabel 4.2

Persentase Taraf Keberhasilan Tindakan

\begin{tabular}{c|c}
\hline Persentase Keberhasilan & Taraf Keberhasilan \\
\hline \hline $86-100$ & Sangat baik \\
\hline $70-85$ & Baik \\
\hline $50-69$ & Cukup \\
\hline \\
\hline $0-50$ & Kurang \\
rdasarkan hasil observasi terhadap aktifitas guru dalam kegiatan
\end{tabular}

pembelajaran pada tabel 3.1 di atas, jumlah skor yang diperoleh 56 dan skor maksimalnya adalah 72 Dengan demikian presentase skornya adalah $77.77 \%$. Hal ini menunjukkan kategori Baik. ${ }^{8}$

Table 4.3

Observasi Aktifitas Guru Selama Proses Pembelajaran Melalui Metode TGT (Teams Games Tournament) Siklus II

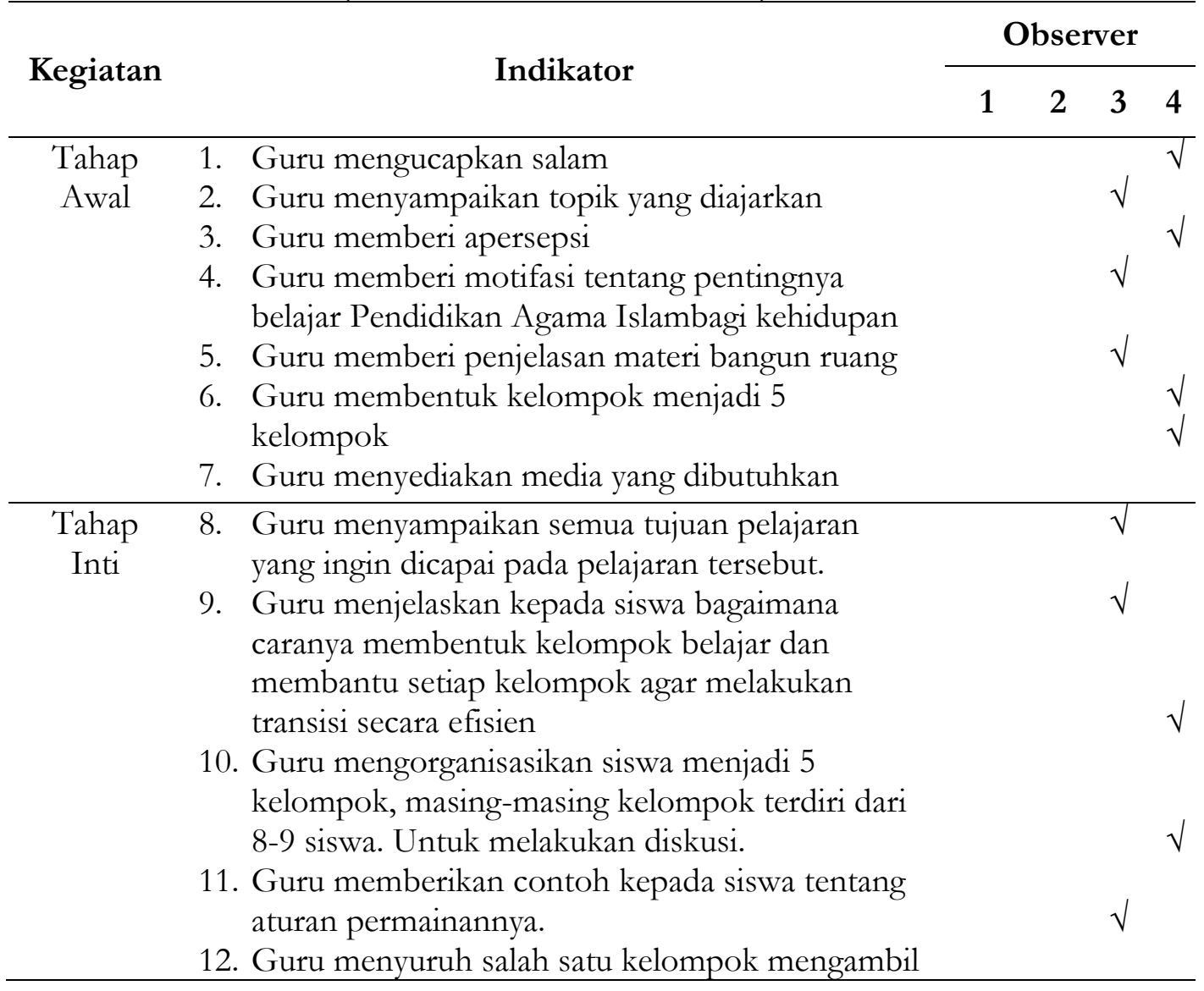

${ }^{8}$ Sardiman Am, Interaksi Dalam Proses Belajar Mengajar (Jakarta: Rajawali Pers, 1988) 


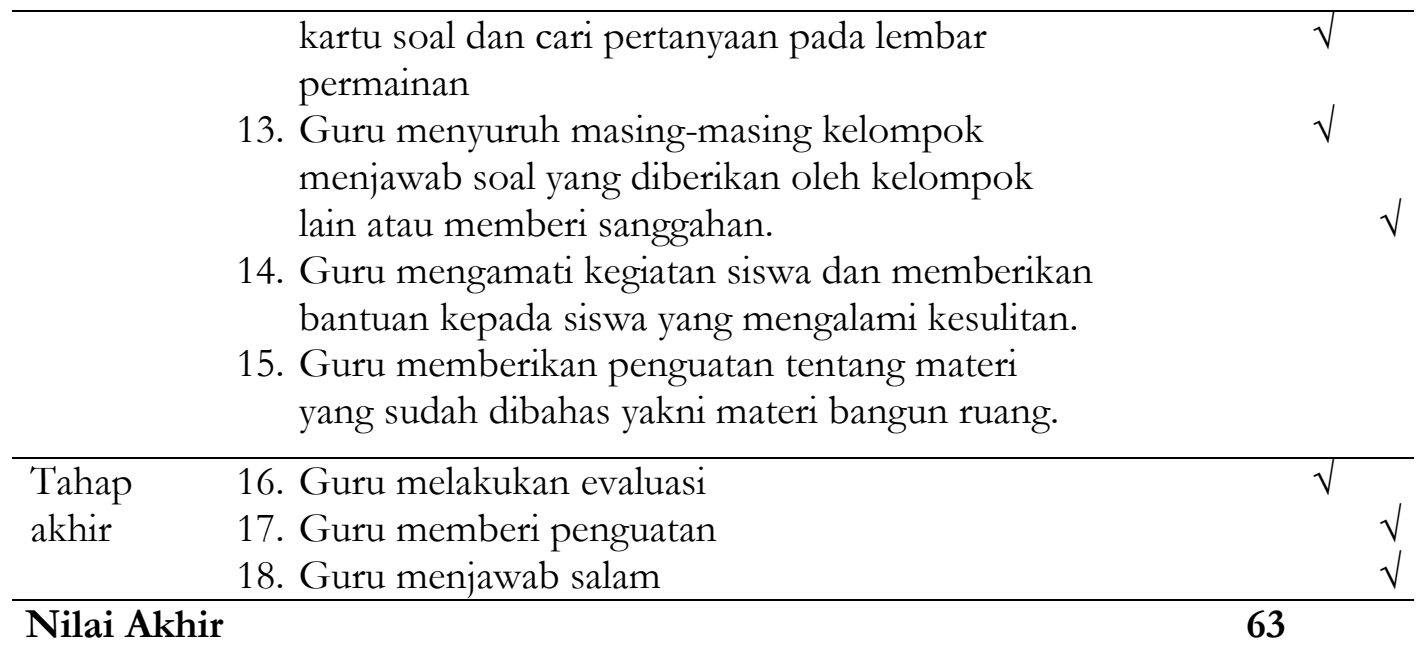

$$
\begin{aligned}
& \text { Nilai }=\frac{\text { Skor Perolehan }}{\text { Skor Maksimum }} \times 100 \% \\
& \text { Nilai }=\frac{63}{72} \times 100=87,50 \%
\end{aligned}
$$

Keterangan: Skor maksimum 72

Berdasarkan hasil observasi terhadap aktifitas guru dalam kegiatan pembelajaran pada table 3.6 di atas, jumlah skor yang diperoleh 63 dan skor maksimalnya adalah 72 dengan demikian prosentase skornya adalah 87,5\%. Hal ini menunjukkan kategori Sangat Baik.

Table 4.4

Observasi Aktifitas Siswa Selama Proses PembelajaranMelalui MetodeTGT

\begin{tabular}{|c|c|c|c|c|}
\hline \multirow{2}{*}{ Kegiatan } & \multirow{2}{*}{ Indikator } & \multicolumn{3}{|c|}{ Observer } \\
\hline & & $\begin{array}{ll}1 & 2\end{array}$ & 3 & 4 \\
\hline $\begin{array}{c}\text { Tindakan } \\
\text { Awal }\end{array}$ & $\begin{array}{l}\text { 1. Siswa menjawab salam } \\
\text { 2. Siswa memperhatikan dan mencatat topik yang } \\
\text { diajarkan } \\
\text { 3. Siswa mendengarkan penjelasan guru tentang } \\
\text { materi bangun ruang } \\
\text { 4. Siswa mendengarkan penjelasan guru tentang } \\
\text { pentingnya Pendidikan Agama Islambagi } \\
\text { kehidupan } \\
\text { 5. Siswa mendengarkan penjelasan guru } \\
\text { 6. Siswa menyiapkan diri untuk berkelompok } \\
\text { 7. Siswa menyiapkan diri untuk melaksanakan tugas } \\
\text { kelompok }\end{array}$ & & $\begin{array}{l}\sqrt{ } \\
\sqrt{ }\end{array}$ & $\begin{array}{l} \\
\sqrt{ } \\
\sqrt{ } \\
\sqrt{ }\end{array}$ \\
\hline
\end{tabular}
(Teams games Tournament) Siklus II 


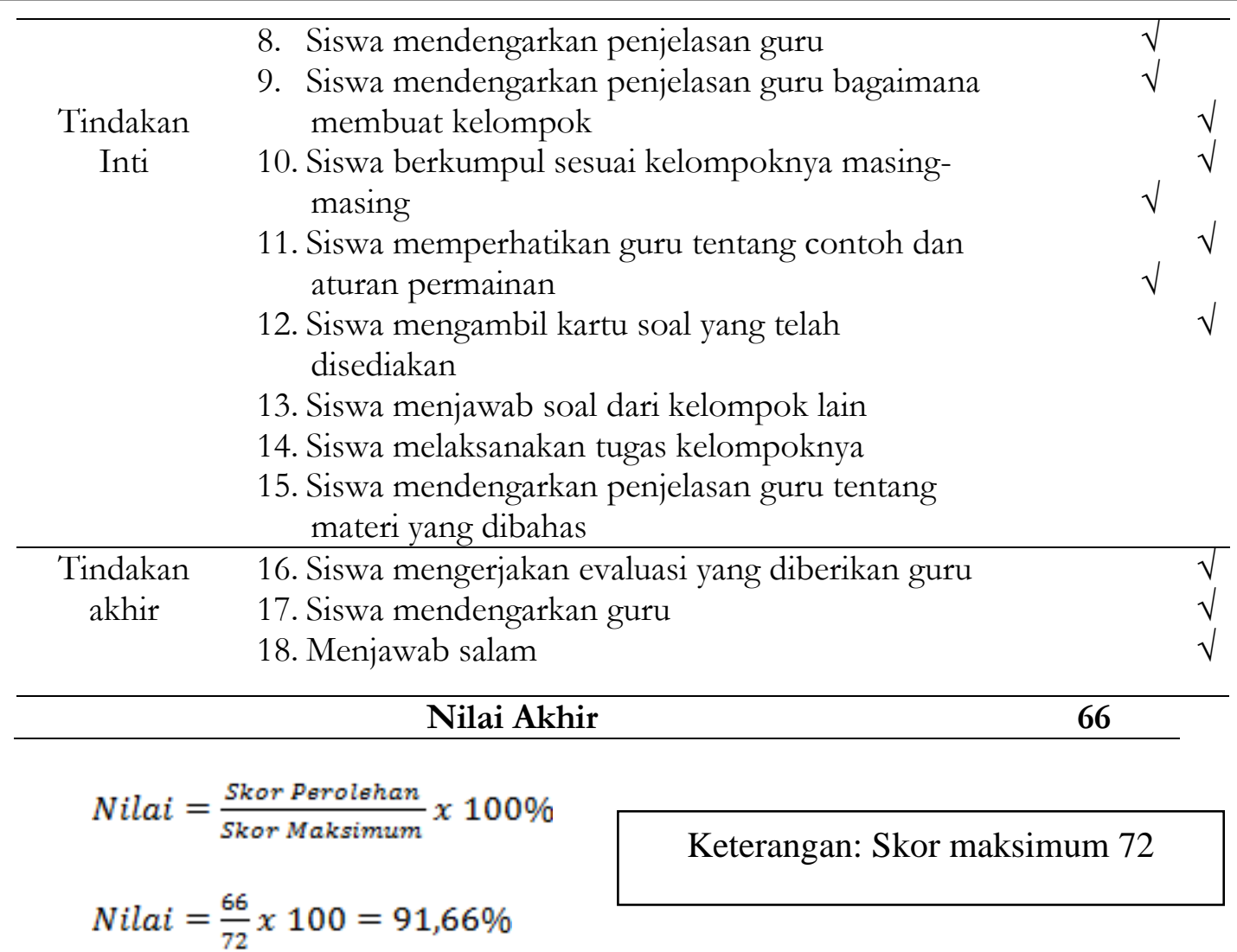

Hasil observasi yang dilakukan oleh peneliti terhadap aktivitas belajar siswa jumlah skor yang diperoleh 66 dan skor maksimalnya adalah 72 Dengan demikian hasil prosentase skor adalah 91,66 \%, yang berarti aktifitas siswa selama kegiatan pembelajaran berada dalam kategori Sangat Baik

\section{Hasil Penelitian Tentang Peningkatan Minat Belajar Siswa}

Data angket guna mengetahui tingkat minat siswa terhadap materi pembelajaran Pendidikan Agama Islamdalam penerapan Metode TGT (Teams Games Tournament),

\section{Analisis Data Penelitian Persiklus}

\section{Pra Siklus}

Tabel 4.6

Rekapitulasi hasil angket minat belajar siswa sebelum diberi tindakan

\begin{tabular}{lllllllllllllllllllll}
\hline $\begin{array}{c}\mathrm{N} \\
\mathrm{O}\end{array}$ & Nama Siswa & 1 & 2 & 3 & 4 & 5 & 6 & 7 & 8 & 9 & 1 & 1 & 1 & 1 & 1 & 1 & Sk & $\mathbf{N}$ \\
\hline \hline & & $\begin{array}{l}\text { M. Adi Indra } \\
\text { Pangestu }\end{array}$ & 4 & 4 & 3 & 4 & 4 & 3 & 3 & 3 & 4 & 2 & 3 & 3 & 4 & 3 & 1 & 48 & $\mathbf{6 4}$ \\
\hline & $\begin{array}{l}\text { Ratna Dwi } \\
\text { Hardiyanti }\end{array}$ & 3 & 4 & 3 & 3 & 4 & 3 & 4 & 4 & 4 & 3 & 3 & 3 & 3 & 3 & 3 & 50 & 7 \\
\hline
\end{tabular}


3 -

\begin{tabular}{|c|c|c|c|c|c|c|c|c|c|c|c|c|c|c|c|c|c|c|}
\hline & Ali Feriyanto & 4 & 3 & 3 & 3 & 3 & 3 & & & & 4 & 3 & 3 & 3 & 4 & 4 & 49 & 3 \\
\hline 4 & Andini Rahmawati & 3 & 3 & 3 & 4 & 3 & 3 & & & & 4 & 3 & 3 & 3 & 3 & 4 & 48 & 64 \\
\hline 5 & Choirul Anwar & 4 & 4 & 4 & 4 & 4 & 3 & & & & 3 & 4 & 3 & 3 & 4 & 3 & 55 & $\begin{array}{c}73 . \\
3\end{array}$ \\
\hline 6 & Denni Winarno & 3 & 3 & 3 & 3 & 3 & 4 & & & & 4 & 2 & 4 & 3 & 3 & 4 & 49 & $\begin{array}{c}65 . \\
3\end{array}$ \\
\hline 7 & Diana Rahmawati & 3 & 3 & 4 & 3 & 3 & 4 & 4 & 3 & & 4 & 3 & 3 & 3 & 3 & 3 & 48 & 64 \\
\hline
\end{tabular}

$\begin{array}{ccccccccccccccccccc}8 & \text { Dodik Hermanto } & 3 & 3 & 3 & 3 & 3 & 3 & 3 & 3 & 3 & 3 & 3 & 3 & 3 & 3 & 4 & 46 & \mathbf{3}\end{array}$

\begin{tabular}{|c|c|c|c|c|c|c|c|c|c|c|c|c|c|c|c|c|c|c|}
\hline 9 & Emi Dwi Luthfiah & 3 & 4 & 4 & 4 & 4 & 3 & 3 & 3 & 4 & 4 & 4 & 4 & 4 & 4 & 5 & 57 & 76 \\
\hline 10 & Emilia Bidayatus S & 4 & 4 & 4 & 4 & 4 & 4 & 4 & 4 & 3 & 5 & 3 & 4 & 3 & 4 & 3 & 57 & 76 \\
\hline \multirow{2}{*}{11} & Erik Wahyu & & & & & & & & & & & & & & & & & 69. \\
\hline & Firmansyah & 3 & 4 & 4 & 4 & 4 & 4 & 3 & 3 & 3 & 4 & 4 & 3 & 2 & 3 & 4 & 52 & 3 \\
\hline \multirow{2}{*}{12} & Fika Fanesa & & & & & & & & & & & & & & & & & \\
\hline & Kholik & 4 & 4 & 4 & 4 & 4 & 4 & 3 & 3 & 3 & 4 & 4 & 5 & 4 & 3 & 4 & 57 & 76 \\
\hline 13 & Hafid Nasrullah & 3 & 3 & 3 & 3 & 2 & 4 & 3 & 3 & 3 & 4 & 3 & 3 & 2 & 3 & 3 & 45 & 60 \\
\hline \multirow{2}{*}{14} & M. Adi Putra & & & & & & & & & & & & & & & & & \\
\hline & Firdaus & 3 & 3 & 3 & 3 & 3 & 3 & 3 & 4 & 4 & 4 & 3 & 3 & 2 & 3 & 4 & 48 & 64 \\
\hline \multirow{2}{*}{15} & & & & & & & & & & & & & & & & & & 66. \\
\hline & M. Bawazier & 4 & 3 & 3 & 4 & 3 & 3 & 3 & 4 & 4 & 3 & 4 & 3 & 2 & 4 & 3 & 50 & 7 \\
\hline \multirow{2}{*}{16} & & & & & & & & & & & & & & & & & & 61. \\
\hline & M. Fadhil Anshori & 3 & 3 & 3 & 3 & 3 & 4 & 3 & 3 & 3 & 2 & 3 & 3 & 3 & 4 & 3 & 46 & 3 \\
\hline \multirow{2}{*}{17} & & & & & & & & & & & & & & & & & & 69. \\
\hline & M. Fani Aliyuddin & 3 & 3 & 3 & 4 & 4 & 4 & 3 & 3 & 4 & 3 & 4 & 3 & 3 & 4 & 4 & 52 & 3 \\
\hline \multirow{2}{*}{18} & M. Nadhiful & & & & & & & & & & & & & & & & & 54. \\
\hline & Arridlo & 2 & 3 & 2 & 3 & 3 & 3 & 2 & 4 & 3 & 3 & 2 & 3 & 3 & 3 & 2 & 41 & 7 \\
\hline \multirow{2}{*}{19} & M. Wawan & & & & & & & & & & & & & & & & & 58. \\
\hline & Arifuddin & 3 & 3 & 4 & 3 & 2 & 3 & 3 & 3 & 3 & 3 & 3 & 3 & 3 & 2 & 3 & 44 & 7 \\
\hline \multirow{2}{*}{20} & M. Yusril Mada & & & & & & & & & & & & & & & & & 69. \\
\hline & Wijaya & 4 & 4 & 4 & 4 & 4 & 4 & 3 & 3 & 3 & 3 & 4 & 3 & 3 & 2 & 4 & 52 & 3 \\
\hline 21 & Mira Yuliana & 4 & 5 & 3 & 3 & 3 & 2 & 3 & 3 & 4 & 4 & 4 & 4 & 5 & 4 & 3 & 54 & 72 \\
\hline \multirow{2}{*}{22} & Moh. Fahmi & & & & & & & & & & & & & & & & & \\
\hline & Hakiki & 4 & 4 & 3 & 3 & 3 & 3 & 3 & 4 & 4 & 3 & 4 & 3 & 3 & 3 & 4 & 51 & 68 \\
\hline 23 & Moh. Fahmi Izza & 3 & 4 & 4 & 4 & 3 & 3 & 3 & 4 & 5 & 3 & 4 & 4 & 4 & 3 & 3 & 54 & 72 \\
\hline \multirow{2}{*}{24} & Moh. Fathur & & & & & & & & & & & & & & & & & \\
\hline & Rozaq & 3 & 4 & 4 & 3 & 3 & 4 & 3 & 3 & 3 & 3 & 3 & 4 & 3 & 3 & 3 & 49 & 65 \\
\hline 25 & Moh. Riki Efendi & 3 & 3 & 3 & 3 & 3 & 3 & 3 & 4 & 4 & 3 & 3 & 4 & 3 & 3 & 3 & 48 & 64 \\
\hline \multirow{2}{*}{26} & M. Dio & & & & & & & & & & & & & & & & & \\
\hline & Ardiansyah & 3 & 4 & 3 & 4 & 4 & 3 & 3 & 4 & 3 & 3 & 3 & 3 & 3 & 4 & 4 & 51 & 68 \\
\hline 27 & M. Irfan Affandi & 3 & 3 & 3 & 3 & 3 & 3 & 3 & 3 & 4 & 4 & 3 & 4 & 3 & 4 & 3 & 49 & 65 \\
\hline 28 & $\begin{array}{l}\text { M. Khilman } \\
\text { Maulana }\end{array}$ & 3 & 3 & 4 & 3 & 4 & 4 & 4 & 3 & 3 & 3 & 3 & 4 & 3 & 4 & 3 & 51 & 68 \\
\hline
\end{tabular}




\begin{tabular}{|c|c|c|c|c|c|c|c|c|c|c|c|c|c|c|c|c|c|c|}
\hline 29 & $\begin{array}{l}\text { Putri Aprilia } \\
\text { Puspita }\end{array}$ & 3 & 4 & 4 & 4 & 3 & 3 & 4 & 4 & 3 & 4 & 3 & 4 & 4 & 3 & 4 & 54 & 72 \\
\hline 30 & $\begin{array}{l}\text { Rahmad } \\
\text { Hardiyanto }\end{array}$ & 3 & 3 & 3 & 3 & 3 & 3 & 3 & 2 & 3 & 3 & 3 & 3 & 3 & 2 & 3 & 43 & 57 \\
\hline 31 & $\begin{array}{l}\text { Rizki Hana } \\
\text { Zulfarani }\end{array}$ & 3 & 3 & 4 & 3 & 3 & 4 & 4 & 3 & 3 & 4 & 3 & 4 & 3 & 3 & 3 & 50 & 67 \\
\hline 32 & $\begin{array}{l}\text { Safira Kintan } \\
\text { Agustin }\end{array}$ & 3 & 3 & 3 & 3 & 4 & 3 & 4 & 3 & 3 & 3 & 3 & 3 & 3 & 4 & 3 & 48 & 64 \\
\hline 33 & Sahrul Gunawan & 3 & 3 & 3 & 3 & 4 & 3 & 3 & 3 & 4 & 3 & 2 & 4 & 3 & 3 & 3 & 47 & 63 \\
\hline 34 & $\begin{array}{l}\text { Silfi Hana } \\
\text { Zulfarani }\end{array}$ & 3 & 3 & 3 & 4 & 3 & 4 & 4 & 3 & 3 & 3 & 2 & 3 & 4 & 4 & 4 & 50 & 67 \\
\hline 35 & $\begin{array}{l}\text { Sita Riyadhatul } \\
\text { Hikmah }\end{array}$ & 4 & 3 & 3 & 3 & 3 & 4 & 3 & 3 & 4 & 3 & 3 & 3 & 4 & 4 & 3 & 50 & 67 \\
\hline 36 & Siti Nur Afifah & 3 & 3 & 3 & 4 & 4 & 4 & 3 & 4 & 3 & 5 & 5 & 4 & 4 & 5 & 4 & 58 & 77 \\
\hline 37 & Uliz Maghfiroh & 3 & 4 & 3 & 3 & 3 & 4 & 3 & 4 & 3 & 3 & 4 & 4 & 3 & 3 & 4 & 51 & 68 \\
\hline 38 & Vera Vebriana & 4 & 4 & 3 & 3 & 3 & 3 & 2 & 3 & 4 & 3 & 3 & 4 & 3 & 3 & 3 & 48 & 64 \\
\hline 39 & $\begin{array}{l}\text { M. Iqbal } \\
\text { Anshorulloh }\end{array}$ & 4 & 3 & 3 & 3 & 3 & 3 & 3 & 3 & 3 & 3 & 3 & 4 & 3 & 3 & 3 & 47 & 63 \\
\hline 40 & $\begin{array}{l}\text { M. Angga } \\
\text { Amirudin }\end{array}$ & 3 & 3 & 3 & 3 & 4 & 3 & 3 & 4 & 3 & 3 & 4 & 3 & 3 & 3 & 3 & 48 & 64 \\
\hline 41 & $\begin{array}{l}\text { M. Ayuhan } \\
\text { Ferdiyansyah }\end{array}$ & 3 & 4 & 3 & 3 & 3 & 3 & 3 & 2 & 3 & 3 & 3 & 4 & 3 & 3 & 3 & 46 & 61 \\
\hline 42 & A.Sukamdi & 3 & 2 & 3 & 3 & 3 & 2 & 2 & 2 & 2 & 3 & 3 & 3 & 2 & 3 & 3 & 39 & 52 \\
\hline 43 & $\begin{array}{l}\text { Bahrudin Rijal } \\
\text { Ashari }\end{array}$ & 3 & 3 & 3 & 3 & 3 & 4 & 3 & 3 & 3 & 3 & 3 & 3 & 3 & 3 & 3 & 46 & 61 \\
\hline & Rata-rata & & & & & & & & & & & & & & & & & $\begin{array}{r}65 \\
91 \\
\end{array}$ \\
\hline
\end{tabular}

\section{a. Tindakan Siklus I}

\section{1) Tahap Perencanaan}

Siklus I berlangsung selama 2 jam pelajaran 2 × 35 menit, dengan materi bangun ruang. Pada siklus ini peneliti merencanakan bahwa dalam pembahasan pokok bahasan bangun ruang menggunakan metode TGT (Teams Games Tournament), siswa kelas V MI NURUL HUDASIDOARJO, sebagian besar kurang meminati pembelajaran Pendidikan Agama Islamdari pembelajaran sebelumnya. Pada tahap ini peneliti mempersiapkan perangkat pembelajaran yang terdiri dari RPP, LKS, soal tes formatif, instrument kegiatan guru dan siswa, instrument penelitian, serta alat-alat pengajaran yang mendukung. ${ }^{9}$

\section{2) Tahap Pelaksanaan}

\footnotetext{
${ }^{9}$ Abdul Majid, Perencanaan Pembelajaran, (Bandung: Pt Remaja Rodaskarya, 2001)
} 
Pelaksanaan kegiatan belajar mengajar untuk siklus I dilaksanakan pada tanggal 5 Maret 2019di kelas V dengan jumlah siswa 43 siswa. Dalam hal ini peneliti bertindak sebagai guru dibantu dengan guru bidang studi yang bersangkutan.Adapun proses belajar mengajar mengacu pada rencana pelaksanaan pembelajaran yang meliputi kegiatan awal, kegiatan inti dan kegiatan akhir. Kegiatan pada awal pembelajaran adalah apersepsi yang dilakukan dengan cara mengaitkan materi yang lalu dengan materi yang akan dibahas (Orientasi). ${ }^{10}$ Kegiatan apersepsi ini dilakukan dengan baik oleh guru. Ketika guru menginformasikan materi pembelajaran yang akan dipelajari dan guru menyampaikan model pembelajaran yang akan digunakan. Siswa tampak senang dan tertarik untuk mengikuti pelajaran. Kegiatan yang dilakukan pada inti pembelajaran yaitu pertama guru mengorientasikan siswa bahwa Pendidikan Agama Islamitu menyenangkan. Kemudian siswa dibagi dalam 5 kelompok dengan masing-masing kelompok terdiri dari 8-9 siswa. ${ }^{11}$

\section{3) Tahap Pengamatan atau Observasi}

\section{b. Tindakan Siklus II}

Pelaksanaan pembelajaran dalam siklus II ini dilaksanakan dalam satu kali pertemuan.Sebagai acuan pelaksanaan tindakan ini, guru perpedoman dari hasil refleksi siklus I, silabus dan desain pembelajaran mata pelajaran Pendidikan Agama Islamyang telah dibuat dan direncanakan sebelumnya. Hasil observasi atau pengamatan adalah sebagai berikut:

\section{1) Tahap Perencanaan}

Perencanaan pada siklus II berdasarkan pada perencanaan yang terdapat pada siklus I. Pada siklus II peneliti lebih meningkatkan kegiatan pembelajaran dari apa yang telah dilakukan pada siklus I Pada siklus ini peneliti merencanakan bahwa dalam pembahasan pokok bahasan bangun ruang menggunakan metode TGT (Teams games Toumament), siswa kelas V MI Nurul Huda Sidoarjo, sebagian besar belum memahami tentang materi bangun ruang dari pembelajaran

${ }^{10}$ Rafi'uddin. Rancangan Penelitian, (Malang: Ikip, 1997)

${ }^{11}$ Nur Hamim Dan Husniyatus Salamah, Penelitian Tindakan Kelas, (Surabaya: Revka Petra Media, 2009) 
sebelumnya. Pada tahap ini peneliti mempersiapkan perangkat pembelajaran yang terdiri dari RPP, LKS, soal tes formatif, instrument kegiatan guru dan siswa, instrument penelitian, serta alat-alat pengajaran yang mendukung.

\section{2) Tahap Pelaksanaan}

Pelaksanaan kegiatan belajar mengajar untuk siklus II dilaksanakan pada tanggal 19 Maret 2019 di kelas V dengan jumlah siswa 43 siswa. Dalam hal ini peneliti bertindak sebagai guru dibantu dengan guru bidang studi yang bersangkutan. Adapun proses belajar mengajar mengacu pada rencana pelaksanaan pembelajaran dengan memperhatikan revisi pada siklus I, sehingga kesalahan pada siklus I tidak terulang lagi pada siklus II. Kegiatan inti, seperi halnya di siklus I siswa berkumpul dengan kelompok asalnya, hal ini dilakukan baik oleh siswa, siswa sudah lebih cekatan dalam membentuk kelompok dan tidak tampak ramai. kemudian guru memberi bimbingan kepada siswa tentang metode TGT, dengan ini siswa tampak antusias dan termotivasi untuk mendemonstrasikan metode TGT tersebut. Setelah melakukan kegiatan pembelajaran di siklus II, guru mata pelajaran dan peneliti melakukan diskusi untuk merefleksi pembelajaran tersebut dan membuat kesimpulan tentang penelitian tindakan kelas ini, karena menerapkan metode TGT (Teams Games Tournament) kepada siswa sudah dirasa berhasil terlaksana. ${ }^{12}$

\section{3) Tahap Pengamatan atau Observasi}

Tabel 4.7

Rekapitulasi hasil angket minat siswa setelah diberi tindakan

\begin{tabular}{|c|c|c|c|c|c|c|c|c|c|c|c|c|c|c|c|c|c|c|}
\hline $\begin{array}{l}\mathbf{N} \\
\mathbf{o}\end{array}$ & $\begin{array}{c}\text { Nama } \\
\text { Siswa } \\
\end{array}$ & 1 & 2 & 3 & 4 & 5 & 6 & 7 & 8 & 9 & $\begin{array}{l}1 \\
0\end{array}$ & $\begin{array}{l}1 \\
1 \\
\end{array}$ & $\begin{array}{l}1 \\
2 \\
\end{array}$ & $\begin{array}{l}1 \\
3\end{array}$ & $\begin{array}{l}1 \\
4 \\
\end{array}$ & $\begin{array}{l}1 \\
5\end{array}$ & Skor & NA \\
\hline 1 & $\begin{array}{l}\text { M. Adi } \\
\text { Indra } \\
\text { Pangestu }\end{array}$ & 5 & 4 & 4 & 4 & 4 & 4 & 5 & 4 & 4 & 4 & 4 & 5 & 5 & 4 & 4 & 64 & 85.3 \\
\hline 2 & $\begin{array}{l}\text { Ratna Dwi } \\
\text { Hardiyanti }\end{array}$ & 4 & 5 & 4 & 4 & 5 & 4 & 5 & 4 & 4 & 3 & 4 & 4 & 5 & 4 & 5 & 64 & 85.3 \\
\hline 3 & $\begin{array}{l}\text { Ali } \\
\text { Feriyanto }\end{array}$ & 5 & 4 & 4 & 4 & 5 & 4 & 4 & 4 & 4 & 4 & 4 & 5 & 4 & 4 & 5 & 64 & 85.3 \\
\hline 4 & Andini & 5 & 5 & 4 & 4 & 4 & 4 & 4 & 4 & 4 & 4 & 5 & 4 & 5 & 4 & 4 & 64 & 85.3 \\
\hline
\end{tabular}

${ }^{12}$ Hudojo Herman, Pengembangan Kurikulum Dan Pembelajaran Matematika, (Malang: Unm, 2003) 
Rahmawati

\begin{tabular}{|c|c|c|c|c|c|c|c|c|c|c|c|c|c|c|c|c|c|c|}
\hline 5 & $\begin{array}{l}\text { Choirul } \\
\text { Anwar }\end{array}$ & 5 & 4 & 5 & 4 & 5 & 4 & 4 & 5 & 4 & 5 & 4 & 5 & 5 & 4 & 5 & 68 & 90.7 \\
\hline 6 & $\begin{array}{l}\text { Denni } \\
\text { Winarno }\end{array}$ & 5 & 4 & 4 & 4 & 4 & 4 & 5 & 4 & 5 & 4 & 4 & 5 & 5 & 4 & 5 & 66 & 88 \\
\hline 7 & $\begin{array}{l}\text { Diana } \\
\text { Rahmawati }\end{array}$ & 4 & 5 & 4 & 4 & 4 & 5 & 4 & 4 & 4 & 4 & 4 & 5 & 5 & 4 & 5 & 65 & 86.7 \\
\hline 8 & $\begin{array}{l}\text { Dodik } \\
\text { Hermanto }\end{array}$ & 5 & 4 & 4 & 4 & 4 & 4 & 5 & 4 & 4 & 4 & 5 & 4 & 4 & 4 & 5 & 64 & 85.3 \\
\hline 9 & $\begin{array}{l}\text { Emi Dwi } \\
\text { Luthfiah }\end{array}$ & 5 & 4 & 5 & 4 & 5 & 5 & 4 & 5 & 4 & 5 & 4 & 5 & 5 & 4 & 5 & 69 & 92 \\
\hline 10 & $\begin{array}{l}\text { Emilia } \\
\text { Bidayatus S }\end{array}$ & 4 & 4 & 4 & 5 & 4 & 4 & 4 & 4 & 4 & 5 & 4 & 4 & 4 & 4 & 5 & 63 & 84 \\
\hline 11 & $\begin{array}{l}\text { Erik } \\
\text { Wahyu } \\
\text { Firmansyah }\end{array}$ & 5 & 4 & 4 & 4 & 5 & 5 & 4 & 5 & 5 & 5 & 4 & 5 & 5 & 4 & 5 & 69 & 92 \\
\hline 12 & $\begin{array}{l}\text { Fika Fanesa } \\
\text { Kholik }\end{array}$ & 5 & 4 & 5 & 4 & 5 & 4 & 4 & 4 & 5 & 4 & 5 & 5 & 5 & 4 & 5 & 68 & 90.7 \\
\hline 13 & $\begin{array}{l}\text { Hafid } \\
\text { Nasrullah }\end{array}$ & 5 & 4 & 4 & 4 & 4 & 5 & 4 & 4 & 4 & 4 & 4 & 4 & 4 & 4 & 5 & 63 & 84 \\
\hline 14 & $\begin{array}{l}\text { M. Adi } \\
\text { Putra } \\
\text { Firdaus } \\
\end{array}$ & 5 & 4 & 4 & 4 & 4 & 5 & 4 & 4 & 4 & 4 & 5 & 5 & 4 & 4 & 4 & 64 & 85.3 \\
\hline 15 & $\begin{array}{l}\text { M. } \\
\text { Bawazier }\end{array}$ & 4 & 4 & 4 & 4 & 4 & 5 & 4 & 5 & 4 & 4 & 4 & 5 & 4 & 4 & 5 & 64 & 85.3 \\
\hline 16 & $\begin{array}{l}\text { M. Fadhil } \\
\text { Anshori }\end{array}$ & 5 & 4 & 4 & 5 & 4 & 4 & 5 & 4 & 4 & 4 & 4 & 5 & 4 & 4 & 4 & 64 & 85.3 \\
\hline 17 & $\begin{array}{l}\text { M. Fani } \\
\text { Aliyuddin }\end{array}$ & 4 & 4 & 4 & 4 & 5 & 4 & 4 & 4 & 4 & 4 & 5 & 4 & 4 & 4 & 5 & 63 & 84 \\
\hline 18 & $\begin{array}{l}\text { M. } \\
\text { Nadhiful } \\
\text { Arridlo }\end{array}$ & 5 & 4 & 4 & 4 & 4 & 5 & 4 & 4 & 4 & 4 & 5 & 4 & 4 & 4 & 4 & 63 & 84 \\
\hline 19 & $\begin{array}{l}\text { M. Wawan } \\
\text { Arifuddin }\end{array}$ & 5 & 4 & 4 & 4 & 5 & 4 & 4 & 5 & 4 & 4 & 5 & 4 & 5 & 4 & 5 & 66 & 88 \\
\hline 20 & $\begin{array}{l}\text { M. Yusril } \\
\text { Mada } \\
\text { Wijaya }\end{array}$ & 5 & 4 & 4 & 4 & 4 & 4 & 4 & 5 & 4 & 4 & 5 & 4 & 3 & 4 & 5 & 63 & 84 \\
\hline 21 & $\begin{array}{l}\text { Mira } \\
\text { Yuliana } \\
\end{array}$ & 5 & 4 & 4 & 5 & 4 & 4 & 5 & 4 & 5 & 4 & 5 & 5 & 5 & 4 & 5 & 68 & 90.7 \\
\hline 22 & $\begin{array}{l}\text { Moh. } \\
\text { Fahmi } \\
\text { Hakiki }\end{array}$ & 5 & 5 & 4 & 4 & 5 & 4 & 5 & 4 & 4 & 5 & 4 & 5 & 5 & 4 & 5 & 68 & 90.7 \\
\hline 23 & Moh. & 5 & 4 & 5 & 4 & 4 & 4 & 5 & 5 & 4 & 5 & 4 & 5 & 5 & 4 & $J$ & 68 & 90.7 \\
\hline
\end{tabular}




\begin{tabular}{|c|c|c|c|c|c|c|c|c|c|c|c|c|c|c|c|c|c|c|}
\hline & Fahmi Izza & & & & & & & & & & & & & & & & & \\
\hline 24 & $\begin{array}{l}\text { Moh. } \\
\text { Fathur } \\
\text { Rozaq }\end{array}$ & 4 & 4 & 5 & 4 & 4 & 4 & 4 & 5 & 4 & 4 & 4 & 3 & 4 & 3 & 3 & 59 & 78.7 \\
\hline 25 & $\begin{array}{l}\text { Moh. Riki } \\
\text { Efendi }\end{array}$ & 4 & 4 & 5 & 4 & 4 & 5 & 4 & 3 & 4 & 2 & 3 & 4 & 4 & 3 & 4 & 57 & 76 \\
\hline 26 & $\begin{array}{l}\text { M. Dio } \\
\text { Ardiansyah }\end{array}$ & 4 & 5 & 4 & 4 & 5 & 4 & 4 & 3 & 4 & 3 & 4 & 4 & 5 & 4 & 4 & 61 & 81.3 \\
\hline 27 & $\begin{array}{l}\text { M. Irfan } \\
\text { Affandi }\end{array}$ & 4 & 4 & 5 & 4 & 4 & 4 & 4 & 5 & 3 & 5 & 3 & 4 & 4 & 4 & 5 & 62 & 82.7 \\
\hline 28 & $\begin{array}{l}\text { M. } \\
\text { Khilman } \\
\text { Maulana }\end{array}$ & 5 & 4 & 4 & 4 & 5 & 4 & 4 & 4 & 4 & 5 & 4 & 4 & 4 & 4 & 4 & 63 & 84 \\
\hline 29 & $\begin{array}{l}\text { Putri } \\
\text { Aprilia } \\
\text { Puspita }\end{array}$ & 4 & 3 & 4 & 5 & 4 & 4 & 4 & 4 & 3 & 4 & 4 & 5 & 4 & 3 & 4 & 59 & 78.7 \\
\hline 30 & $\begin{array}{l}\text { Rahmad } \\
\text { Hardiyanto }\end{array}$ & 4 & 4 & 3 & 4 & 4 & 5 & 4 & 4 & 4 & 4 & 4 & 4 & 4 & 4 & 4 & 60 & 80 \\
\hline 31 & $\begin{array}{l}\text { Rizki Hana } \\
\text { Zulfarani }\end{array}$ & 4 & 4 & 4 & 5 & 4 & 4 & 4 & 5 & 4 & 4 & 4 & 5 & 4 & 4 & 4 & 63 & 84 \\
\hline 32 & $\begin{array}{l}\text { Safira } \\
\text { Kintan } \\
\text { Agustin } \\
\end{array}$ & 5 & 4 & 5 & 4 & 5 & 4 & 4 & 5 & 4 & 5 & 4 & 5 & 5 & 4 & 5 & 68 & 90.7 \\
\hline 33 & $\begin{array}{l}\text { Sahrul } \\
\text { Gunawan }\end{array}$ & 5 & 4 & 4 & 4 & 4 & 4 & 4 & 4 & 5 & 4 & 4 & 4 & 4 & 3 & 4 & 61 & 81.3 \\
\hline 34 & $\begin{array}{l}\text { Silfi Hana } \\
\text { Zulfarani }\end{array}$ & 5 & 4 & 4 & 4 & 5 & 4 & 4 & 5 & 4 & 4 & 3 & 4 & 5 & 4 & 5 & 64 & 85.3 \\
\hline 35 & $\begin{array}{l}\text { Sita } \\
\text { Riyadhatul } \\
\text { Hikmah }\end{array}$ & 3 & 4 & 4 & 5 & 4 & 4 & 5 & 4 & 4 & 5 & 4 & 5 & 4 & 4 & 4 & 63 & 84 \\
\hline 36 & $\begin{array}{l}\text { Siti Nur } \\
\text { Afifah }\end{array}$ & 5 & 4 & 5 & 4 & 5 & 4 & 5 & 4 & 5 & 5 & 4 & 5 & 5 & 4 & 5 & 69 & 92 \\
\hline 37 & $\begin{array}{l}\text { Uliz } \\
\text { Maghfiroh }\end{array}$ & 5 & 4 & 5 & 5 & 4 & 5 & 4 & 4 & 4 & 5 & 4 & 5 & 5 & 4 & 5 & 68 & 90.7 \\
\hline 38 & $\begin{array}{l}\text { Vera } \\
\text { Vebriana } \\
\end{array}$ & 5 & 4 & 4 & 4 & 4 & 4 & 5 & 4 & 5 & 4 & 4 & 4 & 4 & 4 & 4 & 63 & 84 \\
\hline 39 & $\begin{array}{l}\text { M. Iqbal } \\
\text { Anshorullo } \\
\mathrm{h}\end{array}$ & 5 & 4 & 4 & 5 & 4 & 4 & 5 & 4 & 5 & 5 & 4 & 5 & 4 & 5 & 4 & 67 & 89.3 \\
\hline 40 & $\begin{array}{l}\text { M. Angga } \\
\text { Amirudin }\end{array}$ & 5 & 4 & 4 & 5 & 4 & 4 & 5 & 4 & 4 & 4 & 5 & 4 & 4 & 4 & 5 & 65 & 86.7 \\
\hline 41 & $\begin{array}{l}\text { M. Ayuhan } \\
\text { Ferdiyansya } \\
\text { h }\end{array}$ & 4 & 4 & 4 & 4 & 5 & 4 & 4 & 4 & 4 & 3 & 4 & 4 & 4 & 4 & 4 & 60 & 80 \\
\hline
\end{tabular}




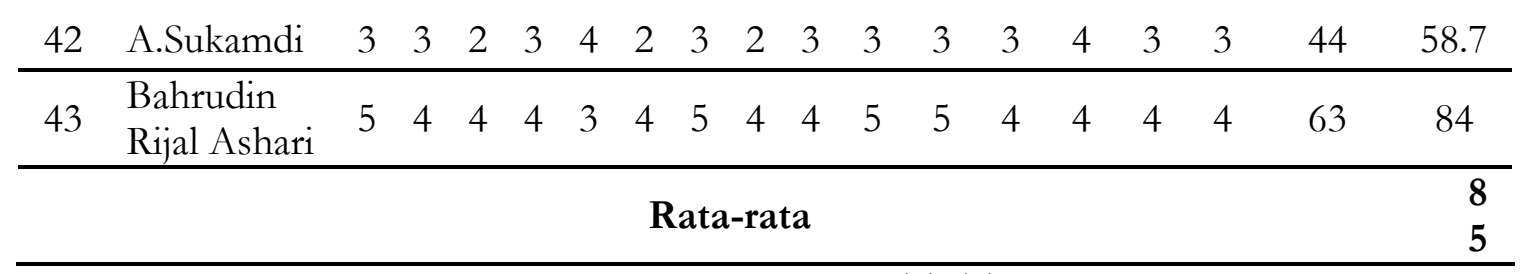

\section{Pembahasan mengenai penerapan metode TGT}

Dari hasil refleksi dan deskripsi data yang telah diuraikan tersebut bahwa ternyata dari segi aktivitas belajar, minat belajar siswa yang diadakan oleh peneliti sudah mencapai hasil yang optimal.Hal ini ditun jukkan denganbertambahnya minat belajar siswa untuk mengikuti pembelajaran Matematika.Dari hasil lembar observasi guru pada siklus I telah menunjukkan bahwa dalam penerapan metode TGT sudah berjalan dengan baik yakni dengan jumlah skor 56 dengan prosentase skornya adalah 77\% atau bisa dikatakan berkategori Baik, sedangkan pada hasil lembar observasi siswa pada siklus I dengan jumlah skor 58 dengan prosentase skor 80,55\% yang dikatakan berkategori Baik. Sedangkan pada siklus II terjadi peningkatan yang signifikan dibanding siklus I, hal ini dapat dibuktikan pada lembar observasi guru pada siklus II yakni memperoleh skor 63 dengan jumlah prosentase 87,5\% yang berkategorikan Sangat Baik, sedangkan pada lembar aktivitas siswa pada siklus II memperoleh skor 66 dengan jumlah prosentase $91,66 \%{ }^{13}$

Pada hasil angket penelusuran minat belajar siswa sebelum diberi tindakan atau pra siklus, siswa kurang meminati pembelajaran Matematika. Hal ini dapat dibuktikan dengan data pada table 4.6 yang hanya memperoleh nilai rata-rata 65,9 yang berkategorikan cukup, dari datayang diperoleh pada siklus I ini penelitiharus membuat tindakan pada siklus selanjutnay untuk mengatasi masalah tersebut, dan masalah tersebut akan dijawab pada siklus II pada table 4.8 yang memperoleh nilai rata-rata 85 yang berkategorikan sangat baik. $^{14}$ Dari data tersebut dapat diketahui adanya peningkatan minat belajar siswa dalam pembelajaran Matematika.

\section{Peningkatan minat belajar siswa dengan metode TGT}

\footnotetext{
${ }^{13}$ Didik Supriyanto, "Pengaruh Pendekatan Saintifik Pada Pembelajaran Seni Budaya Dan Prakarya Terhadap Capaian Akademis Siswa Kelas Iv Di Mi Salafiyah Syafi'iyah Ii Klinterejo Sooko Mojokerto," Naz̧hruna: Jurnal Pendidikan Islam Vol.2, No.2 (2019)

${ }^{14}$ Sudjana, Evaluasi Hasil Belajar, (Bandung: Pustaka Martiana, 1988)
} 
Berdasarkan data yang diperoleh dari hasil penelitian table 4.8 dapat diketahui bahwa pembelajaran menggunakan metode TGT (Teams Games Tournament) dapat meningkatkan minat belajar siswa.Hasil penelitian menunjukkan terjadinya perubahan tingkat belajar siswa di kelas. Dalam pembelajaran siswa terlibat aktif dalam berdiskusi mengemukakan ide dan gagasan yang dilakukan secara berkelompok. Kemudian saat game atau turnamen berlangsung siswa memiliki kesempatan untuk menjawab pertanyaan, berlomba-lomba untuk meraih skor tertinggi sehingga mendapat penghargaan sebagai tim terbaik. ${ }^{15}$

\section{Simpulan}

Berdasarkan hasil penelitian yang telah dipaparkan selama dua siklus, hasil seluruh pembahasan serta analisis yang telah dilakukan dapat disimpulkan bahwa penerapan metode TGT (Teams games Tournament) berjalan dengan baik melalui perbaikanperbaikan pada tiap siklus. Hal ini ditunjukkan dengan peningkatan aktivitas guru dan siswa dalam proses belajar mengajar. Dimana aktifitas guru mengalami peningkatan pada siklus I dari kategori baik menjadi sangat baik pada siklus II. Begitu juga dengan aktivitas siswa mengalami peningkatan selama proses pembelajaran. Hal ini terbukti dari hasil observasi aktivitas siswa pada siklus Iberkategori baik dan meningkat pada siklus II yaitu berkategori sangat baik. Dan peningkatan minat siswa yang ditunjukkan oleh hasil angket minat belajar siswa pada siklus I yang berkategori cukup dan meningkat pada siklus II yang berkategori sangat baik.Terjadi peningkatan minat siswa kelas $\mathrm{V}$ mata pelajaran Pendidikan Agama Islamdi MI Nurul Huda Sidoarjosetelah menggunakan metode TGT (Teams games Tournament) dengan baik. Hal ini dibuktikan dengan keaktifan siswa dalam mengikuti proses belajar mengajar, serta dibuktikan dari hasil penelusuran hasil angket minat belajar siswa yang berkategori sangat baik.

\section{Daftar Pustaka}

Hamim, Nur Dan Husniyatus Salamah. Penelitian Tindakan Kelas. Surabaya: Revka Petra Media, 2009.

Herman Hudojo. Pengembangan Kurikulum Dan Pembelajaran Matematika. Malang: Unm, 2003.

15 Novirawati, "Peningkatan Prestasi Belajar Pendidikan Agama Islamdengan Metode Pembelajaran Kooperatif Model Jigsaw Kelas Iv Sdn Domas Kecamatan Trowulan Kabupaten Mojokerto," Skripsi (Universitas Terbuka, 2009) 
Indriyastuti. Buku Paket Pendidikan Agama Islamkelas. Solo: Pt Tiga Serangkai Pustaka Mandiri, 2012.

Majid, Abdul. Perencanaan Pembelajaran. Bandung: Pt Remaja Rodaskarya, 2001.

Moh. Uzer Usman. Menjadi Guru Profesional. Bandung: Remaja Rosda Karya. 2001.

Novirawati. "Peningkatan Prestasi Belajar Pendidikan Agama Islamdengan Metode Pembelajaran Kooperatif Model Jigsaw Kelas Iv Sdn Domas Kecamatan Trowulan Kabupaten Mojokerto.” Skripsi. Universitas Terbuka. 2009.

Rafi'uddin. Rancangan Penelitian. Malang: Ikip, 1997.

Sardiman Am. Interaksi Dalam Proses Belajar Mengajar. Jakarta: Rajawali Pers, 1988.

Sudjana. Evaluasi Hasil Belajar. Bandung: Pustaka Martiana, 1988.

Sugiyono. Metode Penelitian Kuantitatif Kualitatif Dan RD. Bandung: Alfabeta, 2008.

Sumanto, Y.D. Gemar Matematika. Jakarta: Pusat Perbukuan Departemen Pendidikan Nasional. 2008.

Supriyanto, Didik. "Pengaruh Pendekatan Saintifik Pada Pembelajaran Seni Budaya Dan Prakarya Terhadap Capaian Akademis Siswa Kelas Iv Di Mi Salafiyah Syafi'iyah Ii Klinterejo Sooko Mojokerto”. Nað̧runa: Jurnal Pendidikan Islam Vol.2, No.2 (2019).

Supriyanto, Didik. "Modeling” Jurnal Program Studi Pgmi Vol.2, No. 2 (2015). Http://Jurnal.Stitnualhikmah.Ac.Id/Index.Php/Modeling/Article/View/67.

Tim Dosen Unesa. Model-Model Pembelajaran Inovatif, Surabaya: Unesa University Press, 2009.

Trianto. Mendesain Model Pembelajaran Inovatif-Progresif. Jakarta: Kencana Prenada Media Group, 2010. 